Jakob de Haan*

\title{
Some Reflections on the Political Economy of Monetary Policy
}

\author{
https://doi.org/10.1515/roe-2019-2001
}

\begin{abstract}
During the past decades, central bank independence has been increased in a large number of countries. However, even an independent central bank does not operate in a political vacuum. For instance, governments generally appoint political allies, presuming that consequently the central bank will follow policies that are in line with the governments' preferences. The first part of this paper reviews recent research on whether the political ideology of the government has any impact on monetary policies pursued. It is argued that if forward-looking data are used to estimate Taylor-rule models for a panel of OECD countries that take country heterogeneity into account, there is no strong evidence for partisan effects on monetary policy. One of the reasons that central bank independence is no longer taken for granted is the acclaimed redistributive effects of monetary policy. The second part of the paper reviews recent research on the impact of conventional and unconventional monetary policy on income and wealth inequality. It is concluded that empirical research provides very mixed evidence on these issues and that it is not well connected to recent theoretical work.
\end{abstract}

Keywords: central bank independence, political economy, monetary policy, income and wealth inequality

JEL-codes: E52, E58, D63, D72, C23

\section{Introduction}

During the past two decades, central bank independence (CBI) has been increased in a large number of countries. Not only in advanced countries, but also in emerging and developing economies central banks have been granted

Article Note: The views expressed are those of the author and do not necessarily reflect the views of DNB.

*Corresponding author: Jakob de Haan, De Nederlandsche Bank, Amsterdam, The Netherlands; and University of Groningen, Groningen, The Netherlands; and CESifo, Munich, Germany, E-mail: Jakob.de.Haan@rug.nl

Ә Open Access. @2021 Jakob de Haan, Published by De Gruyter. (cc) BY This work is licensed under the Creative Commons Attribution 4.0 International License. 


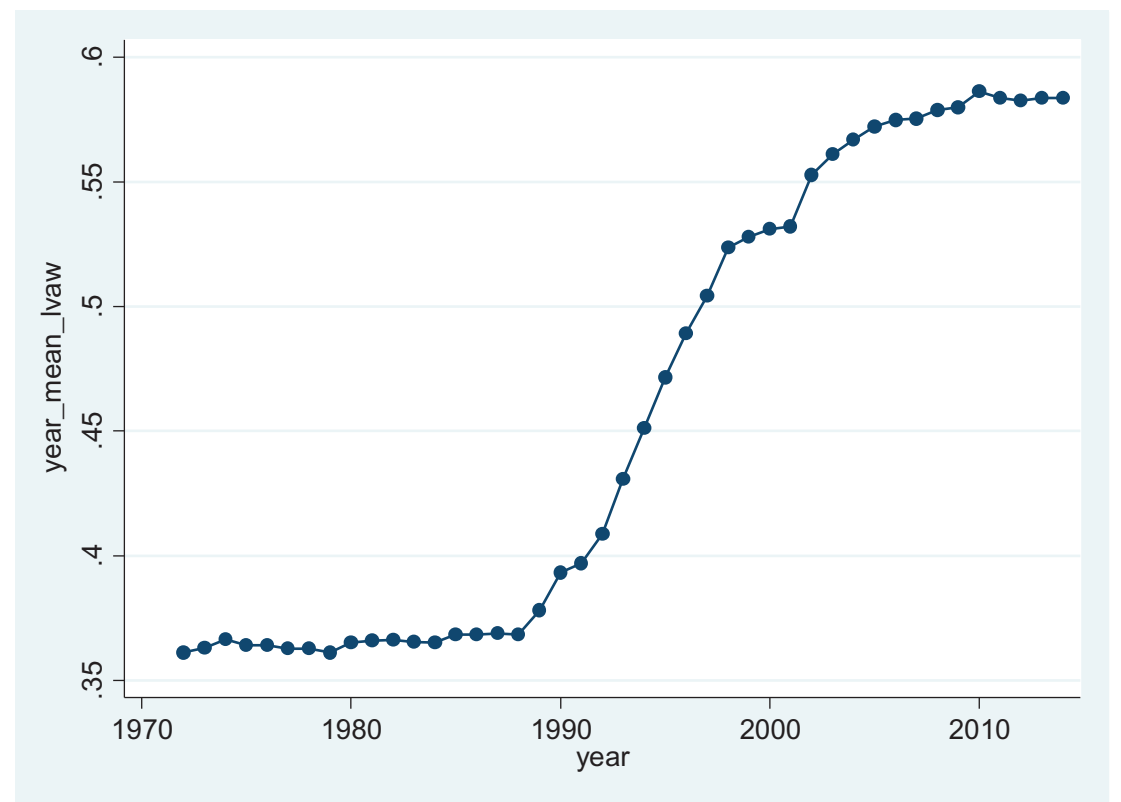

Figure 1: Average central bank independence (all countries), 1970-2014. Source: Updates of BODEA and HICKS (2015).

independence for the conduct of monetary policy. Figure 1 shows the average score of the CBI index as developed by CuKIERMAN, WeBB, and NEYAPTI (1992) and updated by BODEA and HICKS (2015). ${ }^{1}$ There is strong evidence that CBI helps maintaining price stability (KLOMP and DE HAAN, 2010; DE HAAN et al., 2018; КокOSZCZYNSKI and MACKIEWICZ-EYZIAK, 2019 and references cited therein).

Central bank independence means that monetary policy is delegated to unelected officials and that the government's influence on monetary policy is restricted. However, even if a central bank is independent, the central bank does not operate in a political vacuum. Notably when it comes to appointments, politics matters. To illustrate this, Table 1 shows the political affiliation of

\footnotetext{
1 Under the measure of CUKIERMAN, WeBB, and NEYAPTI (1992), a central bank is considered more independent if its charter states that price stability is the sole or primary goal of monetary policy. My interpretation is that the measure of CUKIERMAN et al. captures both central bank independence and central bank "conservativeness as embedded in the law." This is important, as it is the combination of central bank independence and conservativeness that matters as I will explain below.
} 
Table 1: CB governors and government ideology.

\begin{tabular}{llll}
\hline Country: & Governor: & $\begin{array}{l}\text { Political } \\
\text { background: }\end{array}$ & $\begin{array}{l}\text { Government responsible } \\
\text { for Appointment: }\end{array}$ \\
\hline Austria & K. Liebscher & C & S + C \\
Belgium & G. Quaden & S & L + S + \\
Finland & M. Vanhala & C & S + C + L \\
France & J-C. Trichet & C & C \\
Germany & E. Welteke & S & S + \\
Greece & L. D. Papademos & S & S \\
Ireland & M. O'Connell & ? & L \\
Italy & A. Fazio & C & S + C \\
Luxembourg & Y. Mersch & C & C + L \\
Netherlands & N. Wellink & C & S + L \\
Portugal & V. M. Ribeiro & S & S \\
Spain & Constâncio & & \\
\hline
\end{tabular}

Notes: S: socialist or social democratic; C: conservative or christian democratic; L: liberal; + other parties than S, C or L.

Source: BERGER and DE HAAN (2002).

national central bank governors of the ECB's Governing Council some years ago and the composition of the government which appointed these governors. ${ }^{2}$ It is clear that governments generally appoint political allies. What is less clear though, is whether this has any impact on monetary policies pursued. In the first part of my presentation I will discuss recent research on this topic.

There are good reasons for delegating monetary policy to an independent central bank. For example, ALESINA and TABELLINI (2008) argue that delegation of decision-making authority to non-elected bureaucrats is beneficial when the tasks are technical in nature and if those tasks entail a risk of time inconsistency

2 ENNSER-JEDENASTIK (2014) has collected data on the partisan background of 195 centralbank governors in 30 European countries between 1945 and 2012 to test whether partisan congruence between governors and the executive is associated with a higher probability of governor turnover. The author finds that partisan ties to the government strongly increase a governor's odds of survival vis-à-vis non-partisan and opposition-affiliated individuals. 'Hostile' governors face greater odds of removal early in their term, but this effect vanishes after fewer than four years. Based on back-ward looking Taylor rule models for 20 OECD countries, NEUENKIRCH and NEUMAIER (2015) report evidence that governors who are affiliated with a political party put, independent of their career background, an additional weight on output stabilization and show less of a reaction to inflation than governors who are not affiliated to a party. These authors do not consider the specific political background of the governors. 
and the bureaucrats can be trusted to be skilled and unbiased. Monetary policy for sure suffers from a time inconsistency problem. By appointing a central banker who puts less weight on output fluctuations than the government (i. e. a 'conservative' central banker), the inflationary bias of discretionary policy can be reduced. ${ }^{3}$ Politicians may put a higher weight on output than a central banker due to political pressure to boost output in the short run for electoral reasons or the need to finance government spending. The time inconsistency problem of monetary policy can only be reduced if monetary authority is delegated to an independent and conservative central bank. If the central bank would have the same preferences as the government, it would follow the same policies as the government and independence would not matter. Likewise, if the central bank would be fully under the spell of the government, its preferences would not matter. Only if the central bank is more inflation averse than the government, and can decide on monetary policy without political interference, can it credibly promise to keep inflation low (BERGER, DE HAAN and EIJFFINGER, 2001).

Why are central bankers 'conservative'? ADOLPH (2013) argues that many of the influences on bureaucrats' preferences are bound up in their observable career paths. Using central bankers' career paths, ADOLPH (2013) comes up with an index of Central Banker Career Conservatism (CBCC), which depends on how long the central banker has had 'conservative' jobs, where four types of jobs are considered - namely, financial sector, finance ministry, central bank, and government. According to Adolph, the first two are 'conservative', while the latter two are 'liberal'. This classification is based on regressions of inflation and career components, controlling for CBI. It turns out that the CBCC index is strongly related to inflation.

How much evidence is there that politicians and central bankers have different preferences? EHRMANN and FRATZSCHER (2011) use a database containing politicians' statements about the ECB's monetary policy over the first nine years of European Economic and Monetary Union. The authors find that politicians tend to favor lower interest rates on average, because euro-area politicians place a greater weight on employment and growth and a lower weight on price stability than the central bank does. They also find that changes in the relative weight on growth in politicians' preferred reaction functions are driven by the national economic performance, trust in the ECB by the national electorate, the political orientation of governments, and the presence of high public debts or deficits.

3 Political scientists have proposed several other reasons why governments may decide to delegate monetary policy to an independent central bank. See DE HAAN and EIJFFINGER (2019) for an extensive discussion. 
Since the financial crisis, CBI is no longer taken for granted. Notably, the policies introduced after the effective lower bound had been reached, such as quantitative easing $(\mathrm{QE})$, and their consequences led several observers to question the desirability of CBI. For instance, STIGLITz (2013) argues that the

notion of the desirability of an independent central bank was predicated on the belief that monetary policy was a technocratic matter, with no distributional consequences. There was a single policy that was best for all - a view to which the simplistic models that the central banks employed may have contributed, but which was not supported by more general models. There does not, in general, exist a Pareto superior monetary policy. That in turn implies that delegating the conduct of monetary policy and regulations to those who come from and reflect the interests of the financial market is going to result in policies that are not necessarily (and weren't) in society's broader interests.

Still, BERNANKE (2010) argues that

there is a good case for granting the central bank independence in making quantitative easing decisions, just as with other monetary policies. Because the effects of quantitative easing on growth and inflation are qualitatively similar to those of more conventional monetary policies, the same concerns about the potentially adverse effects of short-term political influence on these decisions apply. Indeed, the costs of undue government influence on the central bank's quantitative easing decisions could be especially large, since such influence might be tantamount to giving the government the ability to demand the monetization of its debt, an outcome that should be avoided at all costs.

However, BUITER (2016) argues that this view is no longer shared by everyone. In his view, the threat to $\mathrm{CBI}$

comes both from the wider political and social climate - the rise of populism and of antiestablishment, anti-expert and anti-technocratic sentiment - and from developments specific to central banks. Since the start of the Great Financial Crisis (GFC) in mid-2007, central banks in most advanced economies have become more powerful and political. ... Their mandates have expanded far beyond monetary policy narrowly defined.

Do central bankers agree? BLINDER et al. (2017) asked central bankers and economists their views about the extent to which CBI was threatened during the crisis. The answers, as shown in Table 2, are perhaps surprising. Specifically, the share of respondents who believe that central bank independence either did not change or was reduced only "a little" was more than 90\% among central bank governors and more than $80 \%$ among academics.

What about the future? Academics seem to worry more about future CBI than central bank governors (see Table 3). Only 9\% of central bankers believe that future CBI is threatened either "a lot" or "a moderate amount". However, compared to the crisis experience, central bankers seem to be more worried 
Table 2: Central bank independence under threat during the crisis?

\begin{tabular}{|c|c|c|c|c|c|}
\hline & \multicolumn{2}{|c|}{ Governors } & \multirow[t]{2}{*}{ Academics } & \multicolumn{2}{|c|}{ Chi-sq. } \\
\hline & All & AEs & & vs. all & vs. AEs \\
\hline CB independence was & uring $t$ & $\mathbf{s}\left(\mathbf{N}_{\mathbf{G}}=\right.$ & $A=158)$ & $34.8^{\star \star \star}$ & $15.0^{\star \star \star}$ \\
\hline Gained & 13.0 & 0.0 & 5.1 & & \\
\hline Neither gained nor lost & 79.6 & 93.8 & 43.0 & & \\
\hline Lost a little & 1.9 & 6.3 & 40.5 & & \\
\hline Lost a lot & 1.9 & 0.0 & 4.4 & & \\
\hline Difficult to say & 3.7 & 0.0 & 7.0 & & \\
\hline
\end{tabular}

Percentages of number of responding governors or academics. *** denotes significance at the $1 \%$ level, calculated using Chi-squared tests for the independence of responses of governors and academics. AE: Advanced economies. $\mathrm{N}_{\mathrm{G}} / \mathrm{N}_{\mathrm{A}}$ denotes number of responding governors/academics. Source: BLINDER et al. (2017)

Table 3: Central bank independence under threat in the near future?

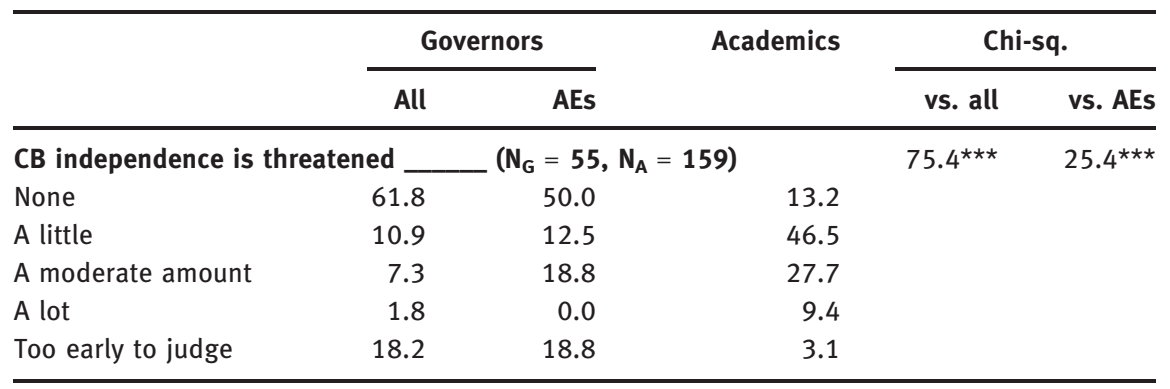

Percentages of number of responding governors or academics. ${ }^{* \star}$ denotes significance at the $1 \%$ level, calculated using Chi-squared tests for the independence of responses of governors and academics. AE: Advanced economies. $\mathrm{N}_{\mathrm{G}} / \mathrm{N}_{\mathrm{A}}$ denotes number of responding governors/academics. Source: BLINDER et al. (2017)

about future CBI: only slightly more than $50 \%$ of central bankers in advanced economies see no threat at all.

An important criterion for delegating a task to bureaucrats that ALESINA and TABELLINI (2008) mention is whether policymakers' actions have first-order distributional effects. The stronger the distributional effects, the less optimal it is to delegate the task to bureaucrats. Although policy interest rate changes transfer wealth between borrowers and lenders, it is widely believed that the primary impact of conventional monetary policy changes is on macroeconomic quantities such as output and inflation and that distributional effects over the cycle are limited. But, as the quote from STIGLITZ (2013) illustrates, not everyone 
ascribes to this view. In the second part of this paper I will therefore discuss what recent research has to say on the distributive consequences of central bank policies.

\section{Partisan influence on monetary policy ${ }^{4}$}

Do central banks follow policies that are in line with the ideological preferences of the government? According to the partisan theory:

conservative parties will pursue more restrictive policies to achieve lower rates of inflation, while left-wing parties will pursue more expansionary policies to achieve lower rates of unemployment. ... In countries with dependent central banks, governments play a significant role in setting monetary policy. As a consequence, monetary policy can be influenced by ... the identity of the party in control of government ... . In countries with independent central banks, on the other hand, governments have, by definition, little influence over the formulation of monetary policy. ... All other things being equal, independent central banks are both more able and more likely than are dependent central banks to resist any domestic political pressure for greater monetary expansion. GoodmAn (1992: 4-5).

In contrast to the prediction of partisan theory, several older studies report evidence that short-term interest rates tend to be higher during left-wing governments (Boix, 2000; Clark, 2003; SAKAmoto, 2008). Boix (2000) and Clark (2003) suggest that left-wing governments follow a tighter monetary policy in order to convince investors or public opinion of their commitment to fight inflation. By following atypical policies, the government aims to earn credibility. SAKАмото (2008) provides another explanation, arguing that lack of control over the central bank incentives left-wing governments to use expansionary fiscal policy, which, in turn, forces independent central banks to increase interest rates. ${ }^{5}$

4 This section heavily draws on Giesenow and De Haan (2019).

5 Alexiadou (2012) argues that most research failed to find evidence of partisan monetary cycles because it did not account for the modifying role of unemployment insurance on policy makers' ability to implement tight monetary policies. If the main reason for resisting higher interest rates is the expectation of higher unemployment rates, then unemployment insurance should minimize the trade-off between employment and economic stabilization. So social democratic parties are more likely to fight inflation effectively when they can provide their constituency with unemployment insurance. Based on backward looking Taylor rule estimates for 17 OECD countries over the period 1970-97, the author reports evidence in support of this view. 
BELKE and POTRAFKE (2012) estimated a dynamic fixed-effects panel model using quarterly data over 1980 to 2005 of 23 developed countries. Their analysis is based on estimates of (backward-looking) Taylor rules incorporating central bank independence and government ideology. The evidence reported by the authors provide support for traditional partisan effects conditional on CBI: short-term interest rates are lower during a left-wing government when the central bank is not independent. However, under independent central banks and left-wing governments, interest rates are higher.

Several previous studies assume that monetary authorities only consider backward-looking information about output and inflation when taking policy decisions. Indeed, in empirical research it is pretty standard to use latestavailable data. However, for modelling policy behavior this is not the proper procedure. The reason, as pointed out by CROUSHORE (2011), is that this approach is based on the heroic assumptions that data are immediately available (when in fact they are generally available only with a lag) and that data revisions either do not exist or are inconsequentially small (when in fact they are often large and may significantly affect empirical results). ${ }^{6}$ In addition, monetary policy instruments (such as the policy interest rate) only affect central bank target variables (such as output and inflation) with substantial delay, making the use of backward-looking information sub-optimal.

In a paper with Fred Giesenow (GIESENOW and DE HAAN, 2019), we use real time, forward looking data in modelling monetary policy, using panel data of 23 OECD countries over the 1980-2005 period. We examine the influence of governments' ideology on the actions of central banks conditional on the level of central bank independence. The model estimated is:

$R_{i t}=\beta_{1} R_{i, t-1}+\beta_{2} I D_{i t}+\beta_{3} C B D_{i t}+\beta_{4} E(\Pi)_{i t}+\beta_{5} E(Y)_{i t}+\beta_{6}(I D x C B D)_{i t}+\eta_{t}+\mu_{i}+\varepsilon_{i t}$,

where, $R_{i t}$ is the short-term nominal interest rate in country $i(i=1,2, \ldots, \mathrm{N})$ during period $t(t=1,2, \ldots, \mathrm{T}), I D_{\text {it }}$ measures the political ideology of the government, $C B D$ is the index for central bank dependence, while $E(\Pi)_{i t}$ and $E(Y)_{i t}$ are the 12-months ahead forecasts of inflation and the output gap available at time $t$, respectively. The model includes country fixed-effects, $\mu_{i}$, to capture

\footnotetext{
6 ORPHANIDES (2001) finds that estimated policy reaction functions for the Federal Reserve based on ex-post data yield misleading descriptions of the Fed's policy-making. Models based on real time Federal Reserve staff forecasts describe policy better than comparable Taylor-type specifications based on ex-post data. GORTER, JACOBS, and DE HAAN (2008) report similar results for the ECB's policies.
} 
individual unobserved time-invariant factors that influence interest rates. Time fixed effects $\eta_{t}$ are also part of the model. The disturbances $\varepsilon_{i t}$ are assumed to be independently distributed across groups.

Forward-looking data, i. e. forecasts for annualized real GDP growth and inflation, have been collected from Consensus Economics (CE). As one of the world's leading economic survey organizations in the world, CE surveys more than 700 economists and institutions each month to obtain their predictions. We used these forecasts in our analysis as central banks' own forecasts are in most cases not available for the time period and frequency considered in our study.

We used a panel set-up for several reasons. First, CE forecasts are not available for a sufficiently long period for most countries and, second, there is not sufficient variation in partisan factors and CBI over time to identify conditional partisan influences in single-country models. However, the use of panel models may cause some problems, the most important one being that it may not be correct to assume that the same data generating process exists in all countries, especially when countries with dissimilar economic and institutional characteristics as Greece and Switzerland are included in the sample (PESARAN and SMITH, 1995). GIESENOW and DE HAAN (2019) employed techniques that allow taking this heterogeneity across countries into account. Our results cast serious doubts on the presence of partisan effects in monetary policy. When the full sample is used and heterogeneous slope coefficients are allowed for by using the mean group estimator, we do not find an association between government ideology and monetary policy (see Table 4).

Table 4: The impact of ideology on forward-looking monetary policy (MG estimator).

\begin{tabular}{|c|c|c|}
\hline Long-run relation & Coefficient & z-value \\
\hline Ideology & -0.396 & -0.4 \\
\hline Central Bank Dependence (CBD) & 0.184 & 0.7 \\
\hline CBD*Ideology & -2.517 & -1.20 \\
\hline (Expected) Output gap & $1.617^{*}$ & 1.88 \\
\hline (Expected) Inflation & $1.872^{\star \star}$ & 2.24 \\
\hline Error correction speed & $-0.214^{\star \star \star}$ & -5.55 \\
\hline Number of $\mathrm{N}$ & \multicolumn{2}{|c|}{21} \\
\hline Observations & \multicolumn{2}{|c|}{935} \\
\hline Period & \multicolumn{2}{|c|}{$1989 / 2005$} \\
\hline
\end{tabular}

Source: GIESENOW and DE HAAN (2019) 


\section{Impact of central bank policies on inequality ${ }^{7}$}

In the aftermath of the global financial crisis, and following the advent of nonstandard monetary policy measures, a debate started about whether, and if so, how monetary policy affects inequality. Three views have been put forward. First, several observers express concerns that a highly accommodative monetary policy, such as quantitative easing, favors richer households disproportionately, thereby contributing to a more unequal income and wealth distribution. Others support the view that expansionary monetary policy may reduce inequality by stimulating economic activity, job creation, and wage growth. These effects, so the argument goes, mainly benefit the poor. Finally, notably central bankers have expressed the view that monetary policy has no first-order effects on inequality. BERNANKE (2015), for instance, argues that "monetary policy is "neutral" or nearly so in the longer term, meaning that it has limited long-term effects on "real" outcomes like the distribution of income and wealth." Proponents of this view point to the fact that inequality has been growing for a long time and is driven by structural factors. The impact of monetary policy on inequality is argued to be transitory, canceling out over the course of the business cycle.

In a recent paper with Andrea Colciago and Anna Samarina (ColCIAGo, SAMARINA, and DE HAAN, 2019), we discussed the rapidly evolving literature on the relationship between central bank policies and income and wealth inequality. In the remainder of this paper, I summarize our main arguments, starting with some remarks about theory.

Inequality is about differences among individuals. Thus, studying the relationship between inequality and central bank policies requires deviating from the representative agent framework. Although models with heterogeneous agents and incomplete markets provide a proper framework for assessing inequality, they have not yet been broadly adopted to evaluate the relationship between inequality and central bank policies. Most policy analyses still employ the Representative Agent New Keynesian (RANK) framework.

Monetary policy in RANK models works almost exclusively through a substitution effect, while income and wealth effects are small. This is so since the representative agent in RANK models is a permanent income consumer and transitory changes in income, due to monetary policy shocks, only exert a minor effect on consumption choices. However, the strong response of aggregate consumption to movements in real rates which characterizes RANK models is at odds with the data.

7 This section heavily draws on Colciago, Samarina, and De Haan (2019). 
How monetary policy affects inequality depends on how households are distributed along relevant heterogeneity dimensions, such as wealth and income. As argued by DolAdo, MotYovszKi, and PAPPA (2018), the same monetary policy action can have different, and potentially offsetting, effects on inequality along different dimensions of heterogeneity. COLCIAGO, SAMARINA, and DE HAAN (2019) identify several transmission channels, reflecting different dimensions of heterogeneity:

- Savings Redistribution Channel. The relevant heterogeneity dimension for this channel is net wealth. A monetary expansion makes borrowers better off by reducing their interest payments on debt, while savers holding deposits face lower returns.

- Unexpected Inflation Channel. The relevant heterogeneity dimensions for this channel are nominally fixed debts and cash holdings. Unexpected inflation causes revaluations of nominal balance sheets, with creditors losing and debtors gaining.

- Interest Rate Exposure Channel. A fall in real interest rates increases financial asset prices. AUCLERT (2016) shows that unhedged interest rates exposures (UREs), i. e. the difference between all maturing assets and liabilities at a point in time, is the correct measure of households' balance sheet exposures to real interest rate changes. Agents whose financial wealth is primarily invested in short-term certificates of deposit tend to have positive UREs, while those with large long-term bond investments or adjustable-rate mortgage liabilities tend to have negative UREs. A drop in the real interest rate causes a redistribution from the first group towards the second group.

- Portfolio Composition Channel. By raising financial asset prices, a fall in the interest rate affects balance sheets of households through differences in the composition of their portfolio of assets. Higher equity prices result in capital gains that benefit high-income households who hold most of financial assets. This raises wealth inequality. At the same time, higher house prices increase the value of real estate assets; this could have equalizing effects if homeownership is broadly distributed among the population, or escalate wealth inequality if homeownership is concentrated at the top of the wealth distribution.

- Earnings Heterogeneity Channel. HeAthCote, PerRI, and Violante (2010) show that while earnings at the top of the distribution are mainly affected by changes in hourly wages, earnings at the bottom are mainly affected by changes in hours worked and the unemployment rate (AMARAL, 2017). To the extent that monetary policy influences these forces differently it will produce redistributive income effects.

- Income Composition Channel. Households acquire their incomes from different sources, each of which may respond differently to changes in monetary 
policy (AMARAL, 2017). Low-income households tend to rely more on transfers, while middle-income households mainly rely on labor income and those at the upper tail of the income distribution rely relatively more on business and capital income. If a fall in interest rates stimulates economic activity, expansionary monetary policy may result in higher wages and lower unemployment, thereby decreasing income.

A nice example of how heterogeneity might be included in a theoretical framework is the study by KAPLAN, MolL, and Violante (2018). These authors introduce financial market incompleteness in New Keynesian models, generating inequality in income, wealth and consumption. They dub the resulting framework as Heterogeneous Agents New Keynesian (HANK) models. In the model of KAPLAN, MOLL, and ViOLANTE (2018), a large fraction of agents has close to zero liquid net wealth. Consumption of these agents is highly sensitive to small and temporary changes in income, but insensitive to interest rate changes. In contrast, households holding wealth, in particular liquid wealth, have the means to smooth consumption in response to small and temporary shocks and adjust their consumption in response to interest rate changes. The analysis of KAPLAN, Moll, and Violante (2018) delivers a key message. The effect on aggregate variables of an interest rate change can be disentangled into two components: an indirect and a direct one. The indirect effect spreads from the change in consumption due to general equilibrium forces, while the direct effect comes from the intertemporal substitution effect which is also present in RANK models. Contrary to RANK models, in HANK models the indirect effect is much stronger than the direct one. The strength of the general equilibrium effect depends on the heterogeneity in wealth holdings across households.

COLCIAGO, SAMARINA, and DE HAAN (2019) also survey empirical research on the relationship between monetary policy and inequality. There is a fair amount of work concerning conventional monetary policy and inequality. On the contrary, research on the inequality effects of unconventional policy is scarce.

The main conclusions coming from our survey are as follows. First, most recent empirical studies on the distributional effects of conventional monetary policy only focus on a few of the transmission channels described in the theoretical literature. Several studies attribute the redistributive effects of a policy shock on income inequality to the income composition and earnings heterogeneity channels.

Second, the evidence on the consequences of conventional policies on inequality is very mixed. Several papers find that contractionary monetary policy increases income and earnings inequality. Other empirical evidence suggests that it is expansionary monetary policy that increases income inequality. 
There seems to be a consensus though that higher inflation, at least above some threshold, increases inequality.

Third, the distributional effects of unconventional monetary policy are not yet well understood. The analyzed non-standard policy measures are mainly based on large-scale asset purchases, while other measures (e.g. low/negative rates) have not received much attention.

Fourth, again the evidence on the consequences of unconventional policies on inequality is very mixed. While the earnings heterogeneity channel suggests that $\mathrm{QE}$ reduces income inequality by stimulating economic activity, job creation, and wage growth, the income composition channel suggests that unconventional policy increases income inequality: by boosting asset prices, capital income of the rich increase and income inequality rises.

Finally, equity returns and house prices are found to be the key drivers of wealth inequality since the Global Financial Crisis, while bond prices had a minor or insignificant impact. Higher house prices have a strong effect on reducing wealth inequality as it benefits a larger group of households, while equity prices have a dis-equalizing effect as capital gains only contribute to the wealth of the top percentile.

There is not much evidence on the inequality effects of the ECB's policies. In a recent study, SAMARINA and NGUYEN (2019) investigate how expansionary monetary policy affects income inequality in 10 euro-area countries over the period 1999-2014. These authors estimate a panel VARX model with an exogenous euro area monetary policy shock identified by a Proxy-SVAR framework. Monetary expansion stimulates output, job creation, and wage growth, benefiting low- and middle-income households and reducing income inequality. At the same time, lower interest rates lead to higher asset prices and capital returns; this may increase income inequality by making rich households better off. Their findings suggest that expansionary monetary policy in the euro area reduces income inequality, indicating that the first channel dominates the second. This outcome is most evident for the periphery countries.

\section{Conclusions}

According to BALls, Howat, and StansBury (2016, p. 12),

The pre-crisis arguments in favour of central bank independence in monetary policy remain strong: if inflationary pressures return, politically-engineered business cycles and time inconsistency are no less likely to be problems than the past, and delegation of authority to an independent expert body remains important for credibility. 
I agree. The research on partisan influences on monetary policy shows that central bank independence is key in minimizing governments' influence on monetary policy. At the same time, CBI should not be taken for granted. There are several developments that may threaten the independence of central banks, including the increasing support for populist parties. Although to date the evidence on the inequality raising effects of monetary policy, notably unconventional monetary policy, is rather mixed, popular perception that these policies may lead to more income and wealth inequality may become a reason why politicians increasingly may want a say in monetary policy.

\section{References}

AdolPh, C. (2013): Bankers, Bureaucrats and Central Bank Politics: The Myth of Neutrality. Cambridge University Press, Cambridge.

Alesina, A. and G. Tabellini (2008): Bureaucrats or Politicians? Part II: Multiple Policy Tasks, Journal of Public Economics 92, 426-447.

Alexiadou, D. (2012): Finding Political Capital for Monetary Tightening: Unemployment Insurance and Partisan Monetary Cycles, European Journal of Political Research 51, 809-836.

AmARAL, P. (2017): Monetary Policy and Inequality, Economic Commentary 2017-01, Cleveland Federal Reserve Bank of Cleveland.

AuClert, A. (2016): Monetary Policy and the Redistribution Channel, Mimeo Stanford.

Balls, E., J. Howat and A. Stansbury (2016): Central Bank Independence Revisited: After the Financial Crisis, What Should A Model Central Bank Look Like? Harvard Kennedy School MRCBG Associate Working Paper Series 67, Harvard University: Cambridge (MA).

Belke, A. and N. Potrafke (2012): Does Government Ideology Matter in Monetary Policy? A Panel Data Analysis for OECD Countries, Journal of International Money and Finance 31, $1126-1139$.

Berger, H. and J. De HaAn (2002): Are Small Countries Too Powerful within the ECB?, Atlantic Economic Journal 30, 1-20.

Berger, H., J. De HAAN and S. C. W. EIJfFinger (2001): Central Bank Independence: An Update of Theory and Evidence, Journal of Economic Surveys 15, 3-40.

BernANKE, B. (2015): Monetary Policy and Inequality. http://www.brookings.edu/blogs/benbernanke/posts/2015/06/01-monetary-policy-and-inequality.

Bernanke, B. S. (2010): Central Bank Independence, Transparency, and Accountability. Speech of Chairman Ben S. Bernanke at the Institute for Monetary and Economic Studies International Conference, Bank of Japan, Tokyo, Japan May 25, 2010, https://www.feder alreserve.gov/newsevents/speech/bernanke20100525a.htm.

Blinder, A. S., M. Ehrmann, J. De HAAN and D. JAnSEn (2017): Necessity as the Mother of Invention: Monetary Policy after the Crisis, Economic Policy 32, 707-755.

BodeA, C. and R. Hicks (2015): Price Stability and Central Bank Independence: Discipline, Credibility and Democratic Institutions, International Organization 69, 35-61. 
BoIX, C. (2000): Partisan Governments, the International Economy, and Macroeconomic Policies in Advanced Nations, 1960-93, World Politics 53, 38-73.

BUITER, W. (2016): Dysfunctional Central Banking. The End of Independent Central Banks or a Return to 'narrow Central Banking' - or Both?, Citi Research 21, December 2016.

CLARK, W. R. (2003): Capitalism, Not Globalism - Capital Mobility, Central Bank Independence, and the Political Control of the Economy. The University of Michigan Press, Ann Arbor.

Colciago, A., A. Samarina and J. De HaAn (2019): Central Bank Policies and Income and Wealth Inequality: A Survey, Journal of Economic Surveys 33(4), 1199-1231.

CRoushore, D. (2011): Frontiers of Real-Time Data Analysis, Journal of Economic Literature 49, 72-100.

Cukierman, A., S. B. WebB and B. NeYAPtI (1992): Measuring the Independence of Central Banks and Its Effects on Policy Outcomes, The World Bank Economic Review 6, 353-398.

De HAAN, J., C. BodeA, R. HICKS and S. C. W. EIJfFinger (2018): Central Bank Independence before and after the Crisis, Comparative Economic Studies 60, 182-202.

De HAAN, J. and S. C. W. EIJfFinger (2019): The Politics of Central Bank Independence, in: R. Congleton, B. Grofman and S. Voigt (eds.) The Oxford Handbook of Public Choice, Oxford University Press, Oxford.

Dolado, J., G. MotyovszKI and E. PAPPA (2018): Monetary Policy and Inequality under Labor Market Frictions and Capital-Skill Complementarity, Mimeo. European University Institute, Florence.

Ehrmann, M. and M. Fratzscher (2011): Politics and Monetary Policy, The Review of Economics and Statistics 93(3), 941-960.

EnNSER-JedenAstik, L. (2014): Party Politics and the Survival of Central Bank Governors, European Journal of Political Research 53, 500-519.

Giesenow, F. and J. DE HAAN (2019): The Influence of Government Ideology on Monetary Policy: New Cross-Country Evidence Based on Dynamic Heterogeneous Panels, Economics and Politics 31, 216-239.

Goodman, J. B. (1992): Monetary Sovereignty. The Politics of Central Banking in Western Europe, Cornell University Press, Ithaca.

Gorter, J., J. JACobs and J. De HAAn (2008): Taylor Rules for the ECB Using Expectations Data, Scandinavian Journal of Economics 110, 473-488.

HeAthCOTE, J., F. PERRI and G. VIOLANTE (2010): Unequal We Stand: an Empirical Analysis of Economic Inequality in the United States, 1967-2006, Review of Economic Dynamics 13, 15-51.

KAPLAN, G., B. MolL and G. VIOLANTE (2018): Monetary Policy according to HANK, American Economic Review 108, 697-743.

KLomp, J. and J. DE HAAN (2010): Inflation and Central Bank Independence: A Meta Regression Analysis, Journal of Economic Surveys 24, 593-621.

KoKoszCZYNSKI, R. and J. MACKIEWICZ-ŁYZIAK (2019): Central Bank Independence and InflationOld Story Told Anew, International Journal of Finance and Economics forthcoming.

NeUENKIRCH, M. and F. Neumaier (2015): Party Affiliation Rather than Former Occupation: the Background of Central Bank Governors and Its Effect on Monetary Policy, Applied Economics Letters 22, 1424-1429.

ORPhANIDES, A. (2001): Monetary Policy Rules Based on Real-Time Data, American Economic Review 91, 964-985.

Pesaran, M. H. and R. Smith (1995): Estimating Long-Run Relationships From Dynamic Heterogeneous Panels, Journal of Econometrics 68, 79-113. 
Sakamoto, T. (2008): Economic Policy and Performance in Industrial Democracies - Party Governments, Central Banks and the Fiscal-monetary Policy Mix. Routledge, London/New York. SAmarinA, A. and A. D. M. NGuYen (2019). Does Monetary Policy Affect Income Inequality in the Euro Area? DNB Working Paper 626.

StiglitZ, J. E. (2013): A Revolution in Monetary Policy: Lessons in The Wake of the Global Financial Crisis. https://pdfs.semanticscholar.org/b88c/ad7e27f78295d953b2b0 c21aee2bd6fb1618.pdf. 